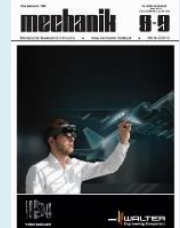

Authors: Łukasz Nowakowski, Edward Miko, Michał Skrzyniarz

Title of article: „Badania wstępne procesu szlifowania czopu wału na frezarce czteroosiowej” (“Preliminary tests of the shaft journal grinding process on a four-axis milling machine")

Mechanik, Vol. 91, No. 8-9 (2018): pages 744-746

DOI: https://doi.org/10.17814/mechanik.2018.8-9.121

\title{
Preliminary tests of the shaft journal grinding process on a four-axis milling machine
}

\section{Badania wstępne procesu szlifowania czopu wału} na frezarce czteroosiowej

\author{
ŁUKASZ NOWAKOWSKI \\ EDWARD MIKO \\ MICHAŁ SKRZYNIARZ *
}

The article presents the results of preliminary tests of the shaft grinding process on a 4-axis AVIA VMC800 milling machine. The carried out tests are a preparation for the development of the face grinding process of a crankshaft pivots of ship engines. Measurements of selected shape errors of the face-ground journal were carried out in the paper.

KEYWORDS: grinding, shaft stub, milling machine, shape errors

The grinding process of large-size and standard crankshafts poses many problems - companies and research and development centers work on their solution. The paper [3] presents the crankshaft oscillation grinding mechanism, in the work [4] - research on the process of grinding crankshafts with high speed, in work [5] - analysis of forces occurring during grinding of crankshafts, and in work [6] - research on the efficiency of the grinding process. The article discusses the preliminary tests of the face grinding process of the shaft end on the AVIA VMC800 fouraxis milling machine.

This direction of research was chosen mainly due to problems occurring during the grinding of large crankshafts of ship engines.

The exemplary shape errors of the polished journal of the ship's engine shaft are shown in fig. 1. The grinding process of this shaft journal was carried out on a grinder whose grinding unit is equipped with a grinding wheel with a diameter of $2000 \mathrm{~mm}$ and a width of $138 \mathrm{~mm}$. The shield has a steel structure, to which two layers are applied by means of glue - intermediate and working, made of CBN each with a thickness of $5 \mathrm{~mm}$. The dial rotates at a speed of $n=300 \div 500 \mathrm{rpm}$. The process of machining the shaft journal takes place in three passes of peripheral depth grinding. A prerequisite for a proper grinding process is obtaining a 90-percent reflection of a flat pattern covered with ink with a thickness of approx. $4 \mu \mathrm{m}$. Unfortunately, as a result of the sanding process currently in use, about $30 \%$ reflection is obtained (fig. 1). The reason for the poor quality of the ground surface are: the positioning errors of the grinder, the low stiffness of the grinding disc and the collisions that occur on the machine tool.

\footnotetext{
* Dr inż. Łukasz Nowakowski (lukasn@tu.kielce.pl), dr hab. inż. Edward Miko, prof. PŚk (emiko@tu.kielce.pl), mgr inż. Michał Skrzyniarz (mskrzyniarz@tu.kielce.pl) - Katedra Technologii Mechanicznej i Metrologii, Politechnika Świętokrzyska
}

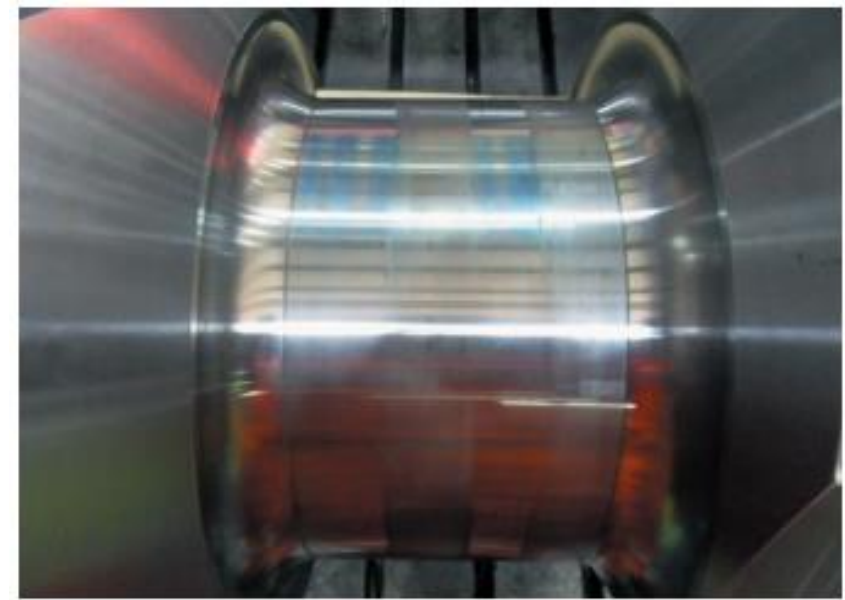

Fig. 1. Crankshaft journal with traces of mascara, which reveal a forming pro-cabinet error

The height differences between the individual grinding wheel inputs are as high as $0.2 \mathrm{~mm}$. Therefore, the shaft end requires a time-consuming manual overcooling process, which can take up to 40 man-hours.

The authors have attempted to grind the shaft journal (scale 1:10) on a 4-axis AVIA VMC800 milling machine. The advantage of this solution is the change of the process of peripheral deep grinding in three passes to the process of frontal longitudinal grinding, which also enabled the use of a smaller tool.

\section{Research methodology}

The first stage of the research involved the preparation of a sample on which three tenons with a diameter of $43 \mathrm{~mm}$ and a length of $19.5 \mathrm{~mm}$ were made, spaced $5 \mathrm{~mm}$ apart. The sample was machined on a CTX 310 ECO lathe, with a TR - D13JCL 2020K knife equipped with a TR-DC1304-F 4215 insert (fig. 2), with the following cutting parameters:

- cutting speed $v_{\mathrm{c}}=300 \mathrm{~m} / \mathrm{min}$,

- feed per revolution $f_{\mathrm{n}}=0.1 \mathrm{~mm} / \mathrm{rev}$,

- cutting depth $a_{p}=1 \mathrm{~mm}$.

Next, on the Talyrond 365 shape measurement device, roundness deviations (fig. 3) and curves (fig. 4) were measured, and the measurement of the geometrical structure of the surface was carried out on the Talysurf $\mathrm{CCl}$ profiler (fig. 5) [1]. 
The next stage of the research consisted in carrying out the longitudinal grinding of shaft journals on a four-axis AVIA VMC800 milling machine (fig. 6).

The grinding process was carried out using a ście $38 \mathrm{~mm}$ diameter grinding wheel and $19 \mathrm{~mm}$ high height made of pink precious grain corundum EK of grain size 30 . In order to avoid zero grinding speed, the disc axis was moved by 15 $\mathrm{mm}$ relative to the axis of the ground shaft.

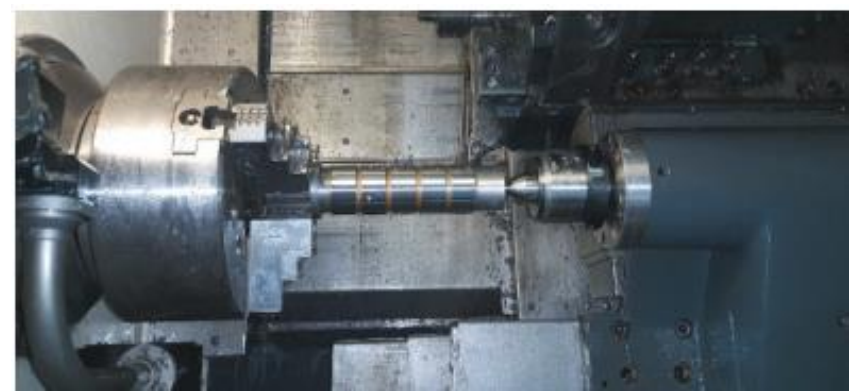

Fig. 2. Turning the samples on the CTX 310 ECO lathe

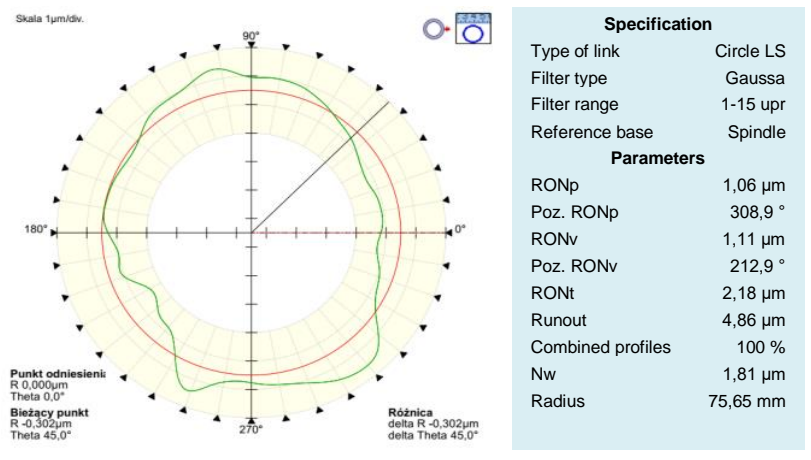

Fig. 3. Parameters and results of roundness deviations of the journal I after turning

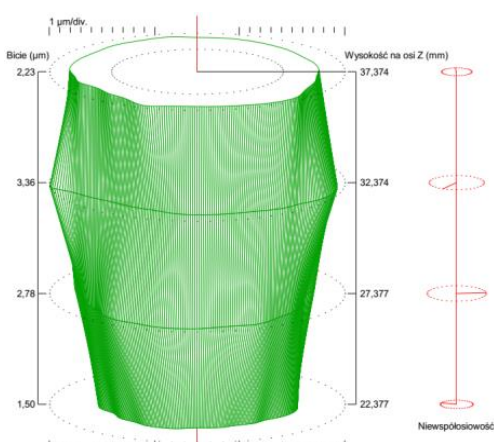

\begin{tabular}{|lr}
\hline \multicolumn{1}{c}{ Specification } & \\
Type of link & Circle LS \\
Filter type & Gaussa \\
Filter range & $1-15$ upr \\
Reference base & Individual \\
Number of planes & 4 \\
\multicolumn{1}{c}{ Parameters } & \\
CyLp & $2,75 \mu \mathrm{m}$ \\
Poz. CyLp & $185,6^{\circ}$ \\
CyLv & $3,11 \mu \mathrm{m}$ \\
Poz. CyLv & $96,6^{\circ}$ \\
CyLt & $5,86 \mu \mathrm{m}$ \\
CyLtt & $8,10 \mu \mathrm{m}$ \\
Poz. CyLtt & $131,8^{\circ}$ \\
Total runout & $5,86 \mu \mathrm{m}$ \\
Average radius & $75,65 \mathrm{~mm}$
\end{tabular}

Fig. 4. Parameters and results of cylindrical deviations of journal I after rolling

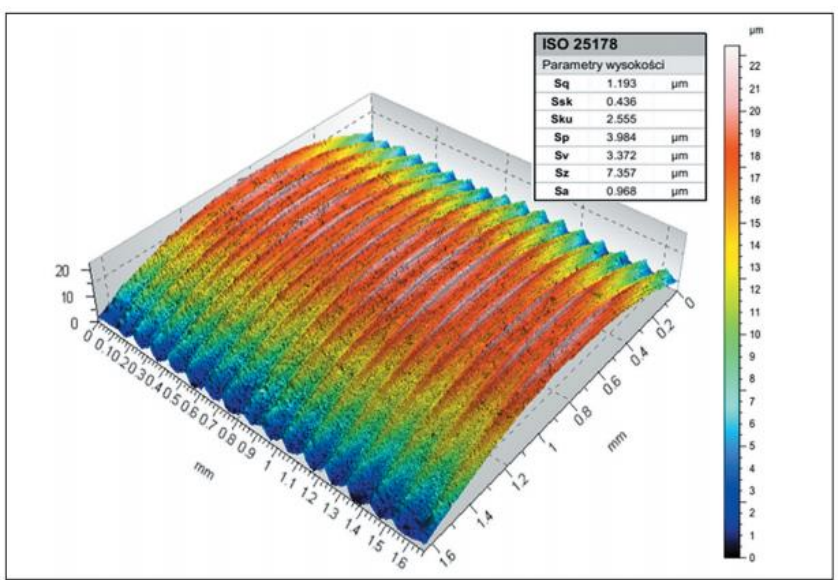

Fig. 5. An example of an SGP of the journal I after turning

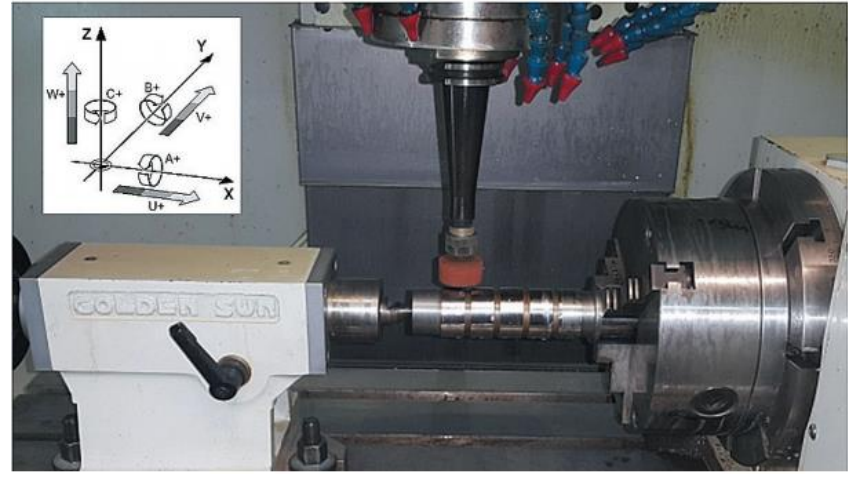

Fig. 6. Stand for carrying out grinding works

The grinding process was carried out with the rotational speed of the milling machine $n=10,000 \mathrm{rpm}$, which gives $v_{\mathrm{c}}$ $=20 \mathrm{~m} / \mathrm{s}$. The speed of the traverse movement was 2 $\mathrm{mm} / \mathrm{rev}$ grooved shaft (single time, full rotation of the shaft is $14.4 \mathrm{~s}$ ) and was realized as a combination of two movements: tool travel in the $X$ axis along the axis of the ground shaft and rotation grinded roller around axis $A$. The depth of cut $a_{\mathrm{p}}$ was $0.02 \mathrm{~mm}$ and its change was achieved by the tool infeed in the $Z$ axis.

In the grinding process, BECHEM AVANTIN 361 I cooling and lubricating liquid was used.

After the grinding process, the roundness deviations (fig. 7) and cylindricity (fig. 8) and the geometric structure of the surface were again measured (fig. 9).

In order to determine the wear of the grinding wheel edge, a transition zone between the turned surface and the ground surface was measured on the Talysurf $\mathrm{CCl}$ profiler. The results of the measurements are shown in fig. 10 and fig. 11.

After analyzing the view presented in fig. 10 and the profile from fig. 11 it was found that the edge of the grinding wheel had worn out for a length of $0.4 \mathrm{~mm}$ (fig. 11).

The results of the roundness and cylindricity measurements of turned and ground pegs are included in the tab. I. Based on these results and shown in fig. 3 and fig. 4 as well as fig. 7 and fig. 8 , it was found that the grinding process slightly improved the roundness deviation on the first two spigots - $4 \mu \mathrm{m}$ and $22 \mu \mathrm{m}$, respectively - and worsened by $6 \mu \mathrm{m}$ in the case of a trunnion III.

It was also found that the grinding process changed the shape of the oval profile, obtained from the rolling process, into a triangular one - the reason for this may be the run-out error of the three-jaw grip, which was max. $20 \mu \mathrm{m}$.

Analyzing the results of cylindricity deviation measurements, it was found that the grinding process increased its value approx. $2 \div 4$ times. The reason for the deterioration of the cylindrical deviation is the error of setting the tailstock axis with respect to the numerically controlled axis of the subdivision. The measurements made using the dial gauge and the cylindrical shape pattern showed a height difference between the $25 \mu \mathrm{m} / 50 \mathrm{~mm}$ centers; the tailstock provided with the machine tool is not adjustable in height.

As a result of the grinding process, a surface was obtained whose dominant component of cylindricity deviation is the shape deviation in the longitudinal section, having the character of a cone (fig. 8).

Tab. II presents a comparison of selected parameters of the geometric structure of the surface, obtained after the rolling and grinding processes [2]. The results of the measurements indicate that the surface roughness parameter $\mathrm{Sa}$ decreased by five times from $0.968 \mu \mathrm{m}$ to $0,171 \mu \mathrm{m}$ due to the grinding process. 


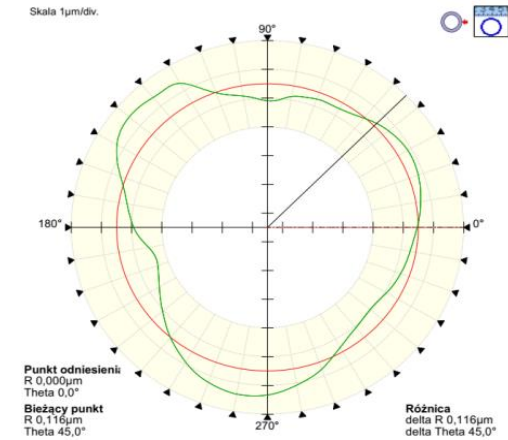

\begin{tabular}{|lr|}
\hline \multicolumn{2}{c}{ Specification } \\
Type of link & Circle LS \\
Filter type & Gaussa \\
Filter range & $1-15$ upr \\
Reference base & Spindle \\
\multicolumn{1}{c}{$\quad$ Parameters } \\
RONp & $0,98 \mu \mathrm{m}$ \\
Poz. RONp & $138,7^{\circ}$ \\
RONv & $1,16 \mu \mathrm{m}$ \\
Poz. RONv & $197,0^{\circ}$ \\
RONt & $2,14 \mu \mathrm{m}$ \\
Runout & $2,55 \mu \mathrm{m}$ \\
Combined profiles & $100 \%$ \\
Nw & $0,50 \mu \mathrm{m}$ \\
Radius & $75,55 \mathrm{~mm}$
\end{tabular}

Fig. 7. Parameters and results of roundness deviations of the journal I after grinding

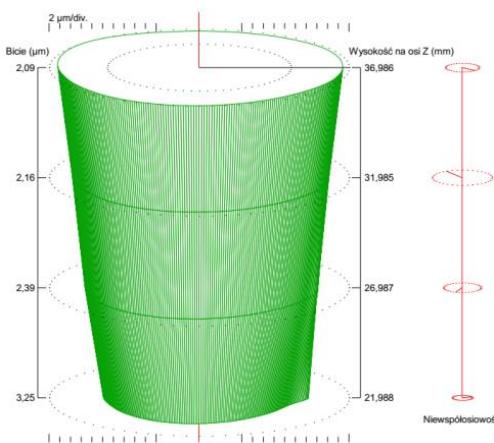

\begin{tabular}{|c|c|}
\hline \multicolumn{2}{|c|}{ Specification } \\
\hline Type of link & Circle LS \\
\hline Filter type & Gaussa \\
\hline Filter range & 1-15 upr \\
\hline Reference base & Individual \\
\hline \multirow{2}{*}{\multicolumn{2}{|c|}{$\begin{array}{l}\text { Number of planes } \\
\text { Parameters }\end{array}$}} \\
\hline & \\
\hline Суцр & $5,16 \mu \mathrm{m}$ \\
\hline Poz. CyLp & $138,3^{\circ}$ \\
\hline CyLv & $5,68 \mu \mathrm{m}$ \\
\hline Poz. CyLv & $326,8^{\circ}$ \\
\hline CyLt & $10,84 \mu \mathrm{m}$ \\
\hline CyLtt & $17,89 \mu \mathrm{m}$ \\
\hline Poz. CyLtt & $89,9^{\circ}$ \\
\hline Total runout & $10,84 \mu \mathrm{m}$ \\
\hline Average radiu & $75,55 \mathrm{~mm}$ \\
\hline
\end{tabular}

Fig. 8. Parameters and results of cylindricity deviation I after grinding

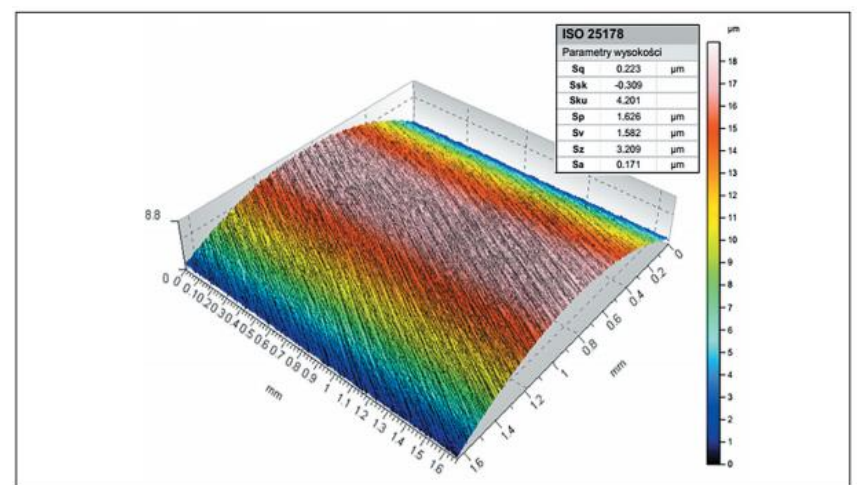

Fig. 9. Example SGP of the journal I after grinding

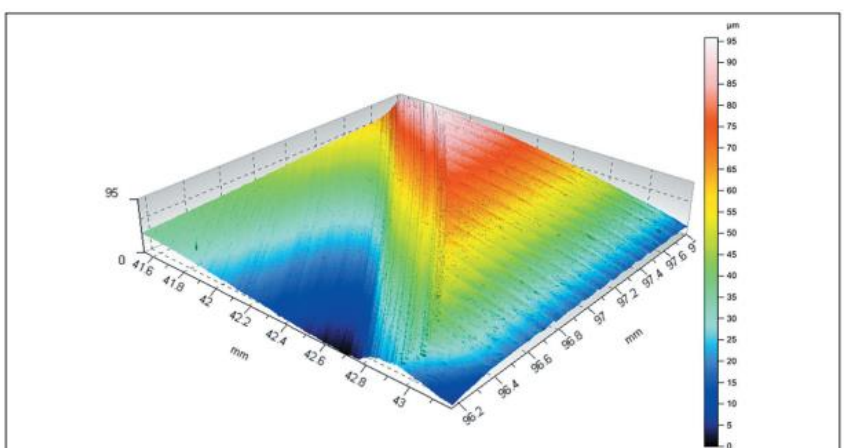

Fig. 10. Cutting zone of the cylinder surface through a grinding wheel

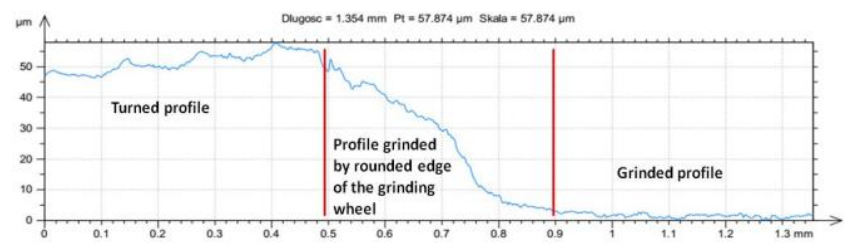

Fig. 11. Profile of the grinding zone (contact) of the roller surface by the grinding wheel
TABLE I.

Results of

measurements of

roundness and

cylindricity

deviations of turned

and ground pivots

\begin{tabular}{|l|c|c|c|c|}
\cline { 2 - 5 } \multicolumn{1}{c|}{} & \multicolumn{4}{c|}{ Roundness deviation, $\mu \mathrm{m}$} \\
\cline { 2 - 5 } \multicolumn{1}{c|}{} & Journal I & Journal II & Journal III & $\Delta$ \\
\hline Turning & 2,18 & 2,43 & 2,11 & 0,32 \\
\hline Grinding & 2,14 & 2,21 & 2,17 & 0,07 \\
\hline \multirow{4}{*}{ Cyylindricity deviation, $\mu \mathrm{m}$} \\
\hline Turning & 5,86 & 3,11 & 2,68 & 3,18 \\
\hline Grinding & 10,84 & 10,54 & 10,98 & 0,44 \\
\hline
\end{tabular}

TABLE II.

Results of SGP

parameters

measurements for

journal I

\begin{tabular}{|c|c|c|}
\hline Process & Turning & Grinding \\
\hline$S q, \mu \mathrm{m}$ & 1,193 & 0,233 \\
\hline Ssk & 0,436 & $-0,309$ \\
\hline$S k u$ & 2,555 & 4,201 \\
\hline$S p, \mu \mathrm{m}$ & 3,984 & 1,626 \\
\hline$S v, \mu \mathrm{m}$ & 3,372 & 1,582 \\
\hline$S z, \mu \mathrm{m}$ & 7,357 & 3,209 \\
\hline$S a, \mu \mathrm{m}$ & 0,968 & 0,171 \\
\hline$R a, \mu \mathrm{m}$ & 0,963 & 1,181 \\
\hline$R s m, \mathrm{~mm}$ & 0,089 & 0,029 \\
\hline$R d q,^{\circ}$ & 8,636 & 4,190 \\
\hline
\end{tabular}

\section{Conclusions}

The process of front longitudinal grinding can be an alternative to circumferential deep grinding of large crankshaft journals.

As a result of grinding the shaft stub on a four-axis milling machine, the geometric structure of the surface was improved, the roundness deviation was slightly improved and a high repeatability of the process was obtained, as evidenced by the small dispersion of cylindricity and roundness deviations. The reduction in cylindricity deviation can be achieved by reducing the error of the tailstock axis with respect to the numerically controlled axis of the dividing block. The next stage of the tests will be the re-grinding process carried out on a four-axis milling machine after introducing changes in the method of clamping the workpiece. In the first place, the axial error of the wheel and the divider must be removed, e.g. by using a tailstock with a regulated height or a can with axial advance. An attempt to grind in the teeth will also be made, which should eliminate or reduce the beating of the grip. Next, a disc with a smaller grain size and a larger diameter will be used, which will increase the speed of grinding.

\section{REFERENCES}

1. Adamczak S., Świderski J., Dobrowolski T. „Analiza wpływu gęstości próbkowania poziomego na parametry chropowatości”. Mechanik. 4 (2017): p. 332-334.

2. Adamczak S., Świderski J. „Narzędzia do analizy porównawczej stanu struktury geometrycznej powierzchni ukształtowanej toczeniem". Mechanik. 10 (2017): p. 906-908.

3. Baron Y.M., Tamaki J., Kuriyagawa T. "Analysis of the grinding mechanism with wheel head oscillating type CNC crankshaft pin grinder". Key Engineering Materials. 291-292 (2005): p. 163-170.

4. Comley P., Walton I., Jin T., Stephenson D.J. "A high material removal rate grinding process for the production of automotive crankshafts". CIRP Annals. 55, 1 (2006): p. 347-350.

5. Walsh A., Baliga B.C., Hodgson P.D. "A study of the crankshaft pin grinding forces". Key Engineering Materials. 257-258 (2004): p. $75-80$.

6. Zhang M. Yao Z "Grinding performance in crankshaft pin journal path-controlled grinding of $40 \mathrm{Cr}$ using CBN wheel". The International Journal of Advanced Manufacturing Technology. 82, 9-12 (2016): p. 1581-1586.

Translation of scientific articles, their computer composition and publishing them on the website www.mechanik.media.p by original articles in Polish is a task financed from the funds of the Ministry of Science and Higher Education designated for dissemination of science. 